\title{
Protection of Farmers' Rights through a Sui Generis System in Indonesia
}

\author{
Nurul Barizah \\ Department of International Law \\ Faculty of Law, Universitas Airlangga \\ Surabaya, 60268, Indonesia \\ nurul.barizah@fh.unair.ac.id
}

\begin{abstract}
The recognition and protection of farmers' rights has not been a top priority in the determination of agricultural policy in the agrarian country of Indonesia, whereas most of the Indonesian

population is farmers (38.07 million). Trade liberalization in agriculture promoted by the World Trade Organization (WTO) also makes farmers increasingly marginalized particularly with the existence of UPOV Convention 1991. The UPOV Convention 1991 provides a strong protection to breeders' rights and limits the rights of farmers which have been recognized previously. Consequently, farmers are not free from fear, threats in innovation and creation, especially in maintaining their local wisdom of storing, buying, swapping and splitting the seeds. Such conditions will ultimately threaten food security in Indonesia. Whereas public international law has laid the foundation for the protection of farmers' rights and ordered the state to regulate it in its national law. This paper aims to analyze how should Indonesia national law recognize and protect farmers' rights to support food sovereignty. This paper offers a sui generis system for the protection of farmers' rights based on fair and equitable principles.
\end{abstract}

\section{Keywords-Farmers' Rights; Sui Generis; Indonesia.}

\section{INTRODUCTION}

The topic of this research is inspired by a condition where the recognition and protection of farmers' rights has not become a major strategic priority in the determination of agricultural policy in Indonesia, whereas this country is the world's largest agricultural country, and home to the center of biodiversity [1]. This means that Indonesia has sufficient resources to ensure food security. However, there are still many Indonesians who have not received sufficient food needed [2]. As a result, food security remains a serious national issue that must be solved.

The strategy of solving national food security problems conducted by the Government has been limited to several aspects concerning; (1) improvement of seed quality and its distribution; (2) crop protection from various diseases; (3) expanding agricultural land; and (4) agrarian reform. However, aspect of human resources (manpower) working in the agricultural sector has not received serious attention from the Government. While the farmers are the main stakeholder in agriculture, and most of Indonesia's population is farmers. Based on data from the Central Bureau of Statistics (BPS), the number of farmers in Indonesia amounted to 38.07 million with wetland area of $8,112,103.00$ ha [3]. Unfortunately, the agricultural policies that provide empowerment and alignment to farmers are limited. The minimum wage of agricultural laborers, for example, is still very low compared to the regional minimum wage and the exchange rate of farmers is declining [4].

On this basis, farmers need legal certainty in carrying out their daily work from various fears, threats in innovating and creating, especially in maintaining local wisdom in storing, selling, buying, swapping and sharing seeds. Furthermore, the existence of farmers was increasingly marginalized in this era of free trade. The provisions of international trade law under the World Trade Organization (WTO) - the Agreement on Trade and Tariff (GATT) 1994, and the implementation of the Agreement on Trade-related Aspect on Intellectual Property Rights (TRIPs)[5] in the agricultural sector greatly affects farmers in developing countries such as Indonesia.

Implementation of Intellectual Property Rights (IPR) protection in agriculture, crops, seeds and biological resources, as a result of the development of modern industrial biotechnology tends to strengthen the position of biotechnologically rich developed nations to exploit the biological resources of the countries that are being developed, protected in patent and plant varieties protection under the TRIPs and UPOV Convention 1991[6]. This Convention provides strict protection against breeders rights, whereas farmers are not included in breeders category under this Convention. This can be considered as the root of injustice in the protection of plant varieties, and lead to seed war at the international fora, thus raising the term "farmers' rights" in1983.

The above analysis shows that the concept of protection of farmers' rights cannot be separated from IPR protection in agricultural sector. In some countries, rigorous IPR protection 
in agriculture make farmers can no longer run agricultural cultures and traditions that promote local wisdom such as the tradition of storing and sharing seeds. As a result, farmers' dependence on the seed industry is getting higher because they have to always buy seeds.

\section{RESEARCH QUESTIONS}

Based on the above background, the legal issues of this research are as follows:

1. To what extent farmers' rights are protected under International Law?

2. To what extent Indonesia implement international law related to the protection of farmers' rights

3. What is the best model for the protection of farmers' rights in Indonesia?

\section{RESEARCH METHOD}

The type of this research is normative legal research by using both primary and secondary legal materials. The primary legal materials is the authoritative legal material made by the authorized institution, while secondary legal material in the form of publication about law which is not an official document. This study uses statutory, conceptual, comparative and historical approaches. The statutory approach used to review all legislations and regulations, both international and national, seeks the ratio legis and philosophical foundation of the provisions on the farmers' rights. The conceptual approach is to examine the concepts, theories and ideas on farmers' right. While historical approach is to analyses the history of farmers' rights protection. Interviews and Focus Group Discussions (FGDs) were also conducted to review the truths of correspondence and obtain stakeholder input.

\section{RESULT AND DISCUSSION}

\section{A. Farmers' Rights under International Law}

As mentioned earlier that the movement of farmers' rights under international fora was a response to the strongest protection of plant varieties rights under the UPOV Convention of 1991. This movement then internationally recognized, and enshrined under Resolution No. 5 of 1989 of the Food and Agriculture Organization (FAO) - International Undertaking on Plant Genetic Resources for Food and Agriculture (IUPGR) [7]. The Resolution No 5 of 1989 has enacted the concept of farmers' rights as follows:

'Farmers' rights mean rights arising from the past, present and future contributions of farmers in conserving, improving, and making available plant genetic resources, particularly those in the centres of origin/diversity. These rights are vested in the international community, as trustee for present and future generations of farmers, for the purpose of ensuring full benefit to farmers, and supporting the continuation of their contributions, as well as the

\author{
attainment of the overall purposes of the \\ International Undertaking'.
}

That Resolution, then reaffirmed in the International Treaty on Plant Genetic Resources for Food and Agriculture (ITPGR)[8] and in other international Conventions, such the Convention on Biological Diversity (CBD)[9], which stipulates the responsibility of national government to realize the farmers' rights related to plant genetic resources for food and agriculture.

The IUPGR was not binding international legal instruments, and accordingly, this Treaty was then changed into binding legal instrument namely the International Treaty on Plant Genetic Resources for Food and Agriculture (ITPGRFA) as mentioned above. This ITPGRFA becomes the main legal instrument dealing with farmers' rights. This ITPGRFA does not define farmers' rights, but provides in its Article 9 (1) as follows:

The Contracting Parties recognize the enormous contribution that the local and indigenous communities and farmers of all regions of the world, particularly those in the centres of origin and crop diversity, have made and will continue to make for the conservation and development of plant genetic resources which constitute the basis of food and agriculture production throughout the world.

That Article clearly acknowledges and recognizes that farmers, local and indigenous communities in the world have significant contribution for conservation of world's plant genetic resources. Furthermore, Article, 9 (2) of ITPGRFA reaffirms that in the realization of farmers' rights, particularly related to plant genetic resources for food and agriculture is the responsibility of the national government in accordance with state's priority. Moreover, still in the same Article, ITPGRFA provides a mandate to each Party subject to national law, and take measures necessary to protect and promote farmers' rights, including:

(1) Protection of traditional knowledge related to genetic resources for food and agriculture;

(2) Right to participate in a fair way in the sharing of benefit which arise from the utilization of plant genetic resources; and

(3) The right to participate in decision making process, at national level, on matters related to conservation and sustainable use of plant genetic resources for food and Agriculture.

In addition, Article 9 (3) of the ITPGRFA stipulates that this Article shall not be interpreted to restrict several rights that farmers have to use, exchange, and sell seeds among farmers or propagation material, subject to applicable and appropriate national laws.

As mentioned earlier, although this Article 9 does not clearly define di detail the definition of farmers' rights, this Article stipulates the scope of such rights which shall be 
implemented by national governments. Such scope, according to Article 9 is as follows:

Farmers' Rights consist of the customary rights of farmers to save, use, exchange and sell farm-saved seed and propagating material, their rights to be recognized, rewarded and supported for their contribution to the global pool of genetic resources as well as to the development of commercial varieties of plants, and to participate in decision making on issues related to crop genetic resources.

Thus, based on the above definition, farmers' rights consist of customary (traditional) rights of farmers to save, use, and exchange, and sell their stored seeds as well as the material for propagation, the right to be recognized and appreciated and supported for their contribution to the collection of world's genetic resources, and the right to participate in decisionmaking on issues related to plant genetic resources.

\section{B. Farmers' Rights under Indonesia Law}

Although international legal instrument dealing with protection of farmers' rights has enacted more than fifteen years ago, and the Indonesian Government is a Party and has ratified such international legal instruments above, but the protection of farmers' rights in Indonesia as mandated by ITPGRFA and CBD is still inadequate. There is no law specifically regulating the protection of farmer's rights in Indonesia.

The provision regulating farmers' rights in Indonesia are contained only in the Plant Varieties Protection (PVP) Act of 2000. Under the Act, farmers' rights are protected, but such protection is very limited and inadequate. The Article 10 of the Act stipulates that the only right granted to the farmer is the use of part of the harvested crops from protected varieties, provided it is not for commercial purpose. Based on the Explanatory Memoranda of the Article 10 (1) a, the meaning of non-commercial purposes under this Article is related to a farmer's individual activities, particularly those of small farmers for their own needs and do not include activities to meet the needs of their group[11]. On this basis, it can be argued that this Act promotes an imbalance in protection between the public's interest and the PVP right holder [12] In addition, this PVP Act appears to protect breeders' rights rather than farmers' rights.

However, the scope of breeders' rights under the Act is very broad and offering a very limited exception for farmers' use, reflects the market-oriented commercial value of the system. This system seems contrary to the agricultural tradition of many Indonesian farmers, particularly those who live in village and rural areas. It is important to note that for many generations, farmers in Indonesia have exchanged seeds amongst the larger farming community. This exchange of seed is part of traditional agricultural wisdom of many Indonesian farmers. It should be noted that they engaged in seed exchange activities not for commercial purposes, but rather out of friendship and solidarity with the community to achieve kerukunan or social harmony[13].

The commercial value of the PVP Act can also be seen in the Article 6(5) which stipulates that the use of new protected varieties, along with the use of essentially derived varieties, requires the authorization of the PVP right holder. This Article can be regarded as another example of the emphasis on the commercial rights of breeders. This provision has a potential to limit the scope for farmers to develop new seed based on their traditional breeding methods for protected new varieties bought from seeding industries, even though this Article mainly aimed to anticipate the development of modern biotechnology techniques of transferring genes with a high degree of certainty. In this context, the PVP system emerges to favour researchers and commercial plant breeders rather than farmers.

Furthermore, Article 1(4) of the Act establishes the following condition in its definition of plant breeding:

Plant breeding is a series of research activities and experiments or the discovery and development of a particular variety, in accordance with, standard methods for the production of new varieties while protecting the purity of the new seed that is produced.

This Article may be interpreted in a way that breeding processes developed by farmers, indigenous and local communities will not be recognized as plant breeding pursuant to the above provision. However, the new varieties developed by commercial plant breeders may be derived from the original plant developed by farmers, but the Act does not clearly the compensation for farmers for developing local varieties used by commercial breeders for creating new varieties[14].

Moreover, the Article 7 (1) of the PVP Act provides that the State controls local varieties owned by a community. The meaning of local varieties refers to already existing varieties that have been cultivated by farmers for generations and have become communal property. The control of the State will be implemented by the Government. This includes regulations on right to payment, the use of local varieties in relation to PVP and other efforts for the conservation of genetic resources. The Government is also responsible for giving a denomination to the local varieties.

In addition, under the Government Regulation No. 13 of 2004, the mayor of the city acting on behalf of the society in their region as the owner of local varieties, has the mandate to control local varieties. Because of that, a prior agreement with the mayor of the city is required by those intending to use local varieties as original varieties for developing essentially derived varieties.

It is important to note that through the PVP Act, the Government asserts controlling authority over plant varieties. In these circumstances the Government may be seeking to exclude outside misappropriation. A local community may reject excessive governmental control over these plants that have been developed. Although this kind of provision is justified by the principle of sovereign control, but is contrary to the principles concerning farmers' rights embodied in the ITPGRFA, and the effort in the CBD- Bonn Guidelines and Nagoya Protocol on Access and Benefit Sharing, to extend the 
control of biological resources to local farmers and communities. In order to adhere to these principles, the state authority over local plant varieties may specify that it will obtain prior informed consent (PIC) and share benefits from local communities, if their varieties are sought for research and commercialization.

The above analyses showed that the protection of farmers' rights in Indonesia is still inadequate, and although the PVP Act is not intended to inhibit small farmers from the opportunity to use new varieties for their own private use and permanently protects local varieties for the benefit and interest of wider society, in practice, the Act has the potential to limit substantially opportunities for small farmers.

\section{Developing Sui Generis System for the Protection of Farmers' Rights}

It would be better if the Indonesian Government develop a sui generis law for the protection of farmers' rights, and to implement the mandates of the ITPGRFA and CBD. In the establishment of such law, national government shall ensure that farmers' are free from fear and intimidation in conducting their daily activities as a farmer, including in maintaining their traditional agricultural knowledge in saving, storing, selling, and exchange of seeds and other propagation material.

Under sui generis law, farmers shall also has a right to participate in all decision making processes related to their interests on plant genetic resources for food and agriculture. Because of that, the CBD principles on prior informed consent (PIC) and mutually agreed terms (MATs) as an instrument to ensure the realization of full participation of farmers shall be clearly regulated.

Access and benefit sharing from the utilization of farmers, local and indigenous communities varieties shall also be regulated in accordance with principles enshrined under the Nagoya Protocol on Access and Benefit Sharing. This access principle is very important to recognize the contribution of farmers, local, and indigenous communities for their contribution in the conservation of world' plant genetic resources. And the scheme of benefit sharing can be in the forms of financial and non financial values.

India, probably one of the examples of the country in the world which provides a sui generis law for the protection of farmers' rights and breeders' rights. Similar to Indonesia, India is a party to a number of international conventions, mainly, the TRIPs Agreement, the CBD, and ITPGRFA, but not to the UPOV Convention. India is also at the forefront in struggling the protection of farmers' rights.

The main legislative instrument enacted by the Indian Government is the Plant Varieties Protection and Farmers' Right Act of 2001. This Act comprises Indian's response to comply with TRIPs obligations, particularly Article 27.3(b) and India's effort to implement the ITPGRFA principles. This Act aimed to provide an effective system for protection of plant varieties, with the rights of both farmers and breeders recognized based on the principle of distributing ownership rights in a fair and equitable mechanism. What is unique about this system is that it extends the notion of Plant Breeders'
Rights (PBR) which typically is only applied to new varieties developed by breeders, to varieties developed by farmers, Non Governmental Organizations (NGOs), and public sector institutions [15]. The Act is a result of the effort to incorporate the interest of various stake holders in plant breeding, including private sector breeders, public sector institutions, research institutions, NGOs and poor farmers [16]. This legislation has offered a model for developing countries, which have similar agricultural traditions and characteristics to India, to provide a balance between breeders' rights and farmers' rights by exploiting the flexibility provided by the TRIPs Agreement [17], and taking into account non-legal factors, including the social and traditional agricultural values of a country.

Under this Act, breeders' rights are adequately protected, as the key provisions dealing with these rights are borrowed mostly from the UPOV Convention, although India is not party to it. Breeders have the right to fully control the formal marketing of their registered variety, including the rights to produce seed, market, distribute, import or export a variety. It also provides strong punishment in the form of imprisonment and fines for those who infringe the breeders' rights. However, the Act provides several important provisions beyond the scope of the UPOV Convention of 1991 dealing with farmers' rights and these provisions were intended to protect farmers from possible negative implications resulting from the operation of breeders' rights.

However, farmers are also granted similar protection. The most significant provision dealing with farmers is the acknowledgement that a farmer's right is to be recognized as an IP right. This notion is contrary to the common perception that farmer's knowledge is merely a traditional part of a common heritage, and accordingly may not be the subject of any IPR protection. The acknowledgement is manifested in providing benefit sharing and compensation to farmers for their roles as cultivators, conservers, and protecting their traditional rights. This Indian Act, explicitly provides that such privileges are recognized as rights. The Section 39 (IV) specifies that:

The farmer shall be deemed to be entitled to save, sow, re-sow, exchange, share or sell his farm produce including seed of a variety protected under this Act in the same manner as he was entitled before the coming into force of this Act; Provided that the farmer shall not be entitled to sell branded seed of a variety protected under this Act.

The formulation of this section is unique, and it is intended to prevent the possible negative effects of the implementation of the Western concept of plant varieties on traditional farmer activities in India. By stating that 'the farmer shall be deemed to be entitled...in the same manner as he was entitled before the coming into force of this Act', this Act provides a statutory guarantee that the existence of the PBR would not reduce and limit the traditional agricultural practice and knowledge of farmers. On the other hand, this provision may implicitly 
recognize the importance of agricultural traditional practice and wisdom for biodiversity conservation.

\section{Conclusion}

This research found that international legal instruments, such as ITPGRFA and CBD has provides adequate protection for farmers' rights as a counter balance the protection of breeders' rights under UPOV Convention. National Government shall ensure that such rights can be implemented under national level in accordance with the principles stipulated under such international legal instrument.

This research also found that, Indonesian legal instrument dealing with protection of farmers' rights is in adequate, and because of that, farmers in Indonesia is not free from fear in conducting their daily activities, particularly for maintaining their traditional agricultural tradition for saving, exchanging, and sharing of seeds.

This research suggests the Government to establish a sui generis law for the protection of farmers' rights. India, can be used as comparison how to formulate the sui generis law and its provisions. In principle, such sui generis law shall embody the principles and norms stipulated under international legal instruments related to the protection of farmers' rights, such as PIC, MATs, and fair and equitable share of benefit.

\section{REFERENCES}

[1] Barbara Laine Kagedan, 'The Biodiversity Convention; Intellectual Property Rights, and Ownership of Genetic Resources; International Ddevelopmet', Report Prepated for Intellectual Property Directorate Industry, Canada, January, 1996, 107.

[2] See in "Pangan untuk Indonesia" [Food for Indonesia], at <http://siteresources.worldbank.org/INTINDONESIA/Resources/Public ation/280016-1106130305439/617331-1110769011447/8102961110769073153/feeding.pdf> last visited Oct 9, 2016.

[3] See in "Rumah Tangga Petani Gurem 2013 Turun 25, 07 Persen dibandingkan 2003" [ Small Farmers Households in 2013 is Decreasing $25,07 \%$ compated to 2003], <http://bps.go.id/index.php/brs/973> last visited Oct 11, 2016.

[4] See in "Nilai Tukar Petani (NTP) Desember 2015 Sebesar 102,83 atau Turun 0,11 persen" [Farmer's Rate (NTP) December 2015 was 102.83 or 0.11 percent lower ", <http://bps.go.id/Brs/view/id/1239> last visited Oct 11,2016 .

[5] Agreement on Trade related Aspects of Intellectual Property Rights (TRIPs) of 1994. Marrakesh Agreement Establishing the World Trade organization, Annex IC, legal Instruments-results of the Uruguay Round. Vol. 31; 33 I.L.M. 1197, 15 April 1994 (entered into force on 1 st january 1995)

[6] International Convention for the Protection of New Varieties of Plants, December 2, 1961, as revised at Geneva on November 10, 1972, on Octobr 23, 1978, and on March 19, 1991.

[7] International Undertaking on Plant Genetic Resources for Foods and Agriculture, 1983, Rome, 5-23 Nov, 1983

[8] International Treaty on Plant Genetic Resources for Food and Agriculture, opened for signature November 3, 2004 (entered into force June 29, 2004), Official text available at <http://fao.org/ag/cgrfa?UI.html>

[9] The United Nation Convention on Biological Diversity, Done at Rio de Janeiro, June 5, 1992, 31 ILM 822, oponed for signature June 5, 1992 (eneted into force December 29, 1993)

[10] Nurul Barizah (1), 'The Indonesian Plant Varieties Protection Act; the Dilemma of Meeting International and Bilateral Obligations and Protecting Traditional Farmers', WIPO -WTO Colloquium Papers; Research Papers from the WIPO-WTO Collouium For Teachers of Intellectual Property Law, 2012, 59-77, 62

[11] Nurul Barizah (2), Intellectual Property Implications on Biological Resources; Indonesia's Adoption of the International Intellectual Property Regimes and the Failure to Adequately Address the Policy Challenges in the Area of Biological Resources (Nagara; 2010), 281.

[12] Graham Dutfield, Intellectual Property Rights and the Life Science Industries: A Twentieth Century History (Ashgate 2003), 216.

[13] Nurul Barizah (1), above n 10,63

[14] Government Regulation Number 13 of 2004 concerning the Penamaan, Pendaftaran dan Penggunaan Varietas Asal untuk Pembuatan Varietas Turunan Essential (Denomination, Registration, and the Use of Original Varieties for Developing Essentially Derived Varieties)

[15] Anitha Ramanna, 'Indian's Plant Variety and Farmers' Rights Legislation: Potential Impact on Stakeholder Access to Genetic Resources', Discussion Paper No. 96, Environment and Production Technology Division (EPTD), International Food Policy and Research Institute, Washington, D.C. USA, January 2003, 1.

[16] S.K. Verma, S.K Verma, 'Plant Genetic Resources, Biological Inventions and Intellectual Property Rights; The Case of India', in Burton Ong (ed), Intellectual Property and Biological Resources (Marshall Cavendish Academic, Singapore, 2005) 128-162.

[17] S.K. Verma, S.K Verma, 'Plant Genetic Resources, Biological Inventions and Intellectual Property Rights; The Case of India', in Burton Ong (ed), Intellectual Property and Biological Resources (Marshall Cavendish Academic, Singapore, 2005) 128-162, 